\title{
Duygusal Emek Ölçeği: Ölçek Geliştirme, Güvenilirlik ve Geçerlilik Çalışması
}

\author{
Emotional Labor Scale: A Study of Scale Development, Reliability and \\ Validity
}

Tuğba PALA', Olca SÜRGEVIL²

\begin{abstract}
ÖZET
Bu çalışmanın amacl; "duygusal emek" olgusunu ölçmeye yönelik Türkiye'deki hizmet sektörü çalışma koşullarına uygun bir ölçek geliştirmektir. Madde havuzu oluşturulması, kapsam geçerliliği, uygulama, yapı geçerliliği ve ölçek güvenilirliği hesaplaması aşamalarından oluşan çalışmanın, duygusal emek konusu ile ilgili çalışan araştırmacılara katkı sağlaması umulmaktadır. Çalışma kapsamında gerçekleştirilen uygulama ve analiz sonuçlarında; yüzeysel davranış, duyguların bastırılması ve derin davranış olmak üzere üç boyuttan oluşan bir duygusal emek ölçeğine ulaşılmıştır.
\end{abstract}

Anahtar Kelimeler: Duygusal emek, ölçek geliştirme, geçerlilik, güvenilirlik

\section{GíRiş}

Örgüt yaşamı, duygu yönetimi ile ilgili örneklerle doludur. Farklı sektörler, hangi duyguların gösterilmesi, hangilerinin dizginlenmesi gerektiğine ilişkin kurallar belirlemiş gibidir. Bu bir anlamda, farklı sektörlere ilişkin farklı "duygu kültürlerinin" oluşması anlamına gelir. Bankacılık, kozmetik, mühendislik, cenaze işleri, reklamcılık, acentecilik vb. birçok sektörde "duygu kültürü"birbirinden oldukça farklıdır. Birbirinden farklı "duygu kültürleri" var olsa da yüz yüze iletişimin sıkça yer aldığı hizmet sektöründe genellikle çalışandan beklenen, müşteriye karşı güler yüzlü ve nazik olmasıdır.

Bu duygu kültürü çeşitliğinde, çalışanlar; kendi duygularını örgütlerinin kültür ve iklimlerine uyumlu şekilde yönetmek durumunda kalmışlardır. Çalışanlar duygularını; çalışan-müşteri arasındaki etkileşimde örgütün istediği yönde ve yine çalışanyönetici etkileşiminde de iyi ilişkiler sürdürme amacıyla yönetmektedirler. Duyguların yönetimi, örgüt içinde çatışmaların azaltılması ve uyumun

\begin{abstract}
The aim of this study is to develop a scale appropriate to the working conditions of the service industry in Turkey to measure the phenomenon of "emotional labor." It is hoped that the study that constitutes the stages of building an item pool, content validity, application, construct validity and calculation of the reliability of scale will contribute to researchers working on emotional labor. As a result of the applications and analysis conducted based on this study an emotional labor scale that consists of three dimensions--surface acting, suppression, deep acting--is achieved.
\end{abstract}

Keywords:Emotional labor, scale development, reliability, validity

sağlanması açısından da önemlidir (Mikolajczak, Tran, Brotheridge ve Gross, 2009).

Önemi farklı şekillerde ortaya konulan duygusal emek, yerli ve yabancı yazında önem kazanmış; konuyla ilgili yapılan araştırmalarda, özellikle 90'ı yılardan sonra büyük bir artış gözlenmiştir. Konuyla ilgili çalışan araştırmacılardan Hochschild (1983), Kruml ve Geddes(2000), Ashforth ve Humphrey (1983), Morris ve Feldman (1995) tarafından yapılan çalışmalar; birçok araştırmacı tarafından referans kabul edilmiştir. Bu araştırmalara örnek olarak Brotheridge ve Lee (2003), Chu ve Murmann (2006) ve Diefendorff, Croyle ve Grosserand (2005)'ın ölçek geliş̧tirme çalışmaları verilebilir.

Gelişmiş ülkelerin çoğunda ekonomi, imalat sektöründen hizmet sektörüne doğru bir geçiş yaşamaktadır; bu geçiş ile birlikte işlerin niteliği değişmekte, çalışanlar kas güçlerinden çok müşteriler ile iyi iletişim kurabilme becerileri doğrultusunda işe alınmaktadır (Chu ve Murmann, 2006). Örgütler, bu noktada çalışanlarının duygularına önem vermekte 
ve bu duyguları işletmelerinin verimliliklerini artıracak bir araç olarak görmektedir (Öz ve Man, 2007). Bu nedenle duygusal emek konusu, son yıllarda Türkiye'de yapılan çalışmalarda da kendini göstermektedir (Öz, 2007; Çukur, 2009; Avcı ve Boylu, 2010; Başbuğ, Ballı ve Oktuğ, 2010; Gürsoy, Boylu ve Avcl, 2011; Oral ve Köse, 2011; Yürür ve Ünlü, 2011; Çelik ve Turunç, 2011; Türkay, Ünal ve Taşar, 2011; Kaya ve Özhan, 2012; Basım ve Beğenirbaş, 2012; Pala ve Tepeci, 2014). Ülkemizde duygusal emek olgusu; amir desteği, duygusal emek beklentisi, duygusal emek kontrolü (Türkay, Ünal ve Taşar, 2011), cinsiyet ve demografik değişkenler (Oral ve Köse, 2011; Basım ve Beğenirbaş, 2013), örgütsel destek (Oktuğ, 2013), negatif ve pozitif duygular (Pala ve Tepeci, 2014), örgütte güven (Beğenirbaş ve Turgut, 2014) şeklindeki öncül değişkenlerle; işe bağlılık (Türkay, Ünal, Taşar, 2011), tükenmişlik (Oral ve Köse, 2011; Kaya ve Özhan, 2012; Yıldırım ve Erul, 2013), örgütsel vatandaşlık davranışı (Beğenirbaş ve 2012), işte kalma niyeti (Pala ve Tepeci, 2014), işten ayrılma niyeti (Yürür ve Ünlü, 2011) psikolojik sıkıntı ve iş-aile çatışması (Çelik ve Tunç, 2011), iş tatmini (Pala ve Tepeci, 2014; Oral ve Köse, 2011), iş performansı (Beğenirbaş ve Turgut, 2014)şeklindeki sonuç değişkenlerle ve duygusal tükenmişlik (Yürür ve Ünlü, 2011)şeklindeki ara değişkenlerle ilişkileri bakımından ele alınmıştır. $\mathrm{Bu}$ çalışmaların çoğunda, olgunun ölçülmesinde; Grandey(1999), Chu ve Murrmann (2006), Diefendorff, Croyle ve Grosserand (2005), Brotheridge ve Lee (2003) ölçeklerinden yararlanılarak ölçümler yapılmıştır. Bu ölçeklerle ilgili kapsamlı açıklamalara aşağıda ayrıca yer verilmektedir.

Bu çalışmalar arasında; Türkiye çalışma koşullarına ve Türkiye'deki farklı sektörlere uygun bir duygusal ölçek ölçme aracına duyulan ihtiyacı vurgulayan çalışmalara rastlanmaktadır (Öz, 2007; Çukur 2009; Basım ve Beğenirbaş, 2012; Pala ve Tepeci, 2014). Bu ihtiyacı karşılamak amacıyla, bu çalışmada da duygusal emek olgusuna ilişkin bir ölçek geliştirme çalışması yapmak amaçlanmakta ve konu ile ilgili çalışan araştırmacılara Türkiye'deki hizmet sektörü çalışma koşullarına uygun bir araç sunulması hedeflenmektedir. Bunun yanı sıra Türkiye'ye özgü bir ölçek geliştirilmesi yabancı dillerden çeviri ile oluşturulan ölçeklerin yarattığı dezavantajları ortadan kaldırma konusunda işlevsel olabilir; zira duygusal emek gibi özgün bir olgunun ölçülmesinde ölçekte kullanılan ifadelerin, katılımcıların sahip oldukları kültürel ve kavramsal çerçeve içinden seçilmesi daha sağlıklı veriler toplanmasına katkı sağlayabilmektedir.

$\mathrm{Bu}$ amaç doğrultusunda gerçekleştirilen bu çalışmada; öncelikle duygusal emek kavramı tanıtılmakta, duygusalemeğin boyutlarıhakkındabilgi verilmekte, yazında yer alan farklı ölçme araçları ve boyutlarına ilişkin yapılan incelemeler sunulmaktadır. Son olarak "madde havuzu oluşturulması, kapsam geçerliliği, uygulama, yapı geçerliliği ve güvenilirlik hesaplaması" aşamalarından oluşan ölçek geliştirme süreci hakkında bilgi verilmektedir.

\section{DUYGUSAL EMEK KAVRAMI}

Duygusal emek kavramı, ilk olarak Hochschild (1983) tarafından yazılan“TheManagedHeart: Commercialization of Human Feeling (Yönetilen Kalp: İnsan Duygularının Ticarileştirilmesi)" kitabında tanımlanmıştır. Hochschild duygusal emeği,"hizmetin sahne, çalışanların aktör, müşterilerin de izleyici olarak görüldüğü bir oyun" olarak nitelendirerek; "herkesin görebildiği, örgütün istediği mimik ve jestleri gösterebilmek için duyguların yönetilmesi, ücretle satılan bu nedenle de değiştirilebilen bir değer" olarak tanımlamıştır. Hochschild duygusal emeğin oluşması için gereken koşulları; (1) işin gereği olarak çalışanın yüz-yüze veya sesli iletişim kurması, (2) çalışanın müşteride duygusal bir durum oluşturması, (3) işverenin çalışanın duygusal aktivitelerini kontrol etme fırsatı vermesi olarak sıralamıştır.

Morris ve Feldman (1997), duygusal emeği; "çalışanların örgüt tarafından gösterilmesi istenen duyguları, kişilerarası etkileşimlerine yansıtmaları için harcadıkları bireysel çaba, planlama ve kontrol" şeklinde tanımlarken; Ashforth ve Humphrey (1993) de, "bir hizmet karşılaşması boyunca örgüt tarafından istenilen duyguların yansıtılması" olarak açıklamıştır. Bu tanımların ortak noktası, çalışanların hissettikleri duyguları, örgüt tarafından gösterilmesi istenen duygular doğrultusunda düzenlemesi ve sergilemesidir.

Hochschild'in (1983) araştırmalarından bu yana, duygusal emekle ilgili yapılan çalışmalar artış göstermektedir. Konuyla ilgili çalışan araştırmacılar, duygusal emeğin sonuçları ile ilgili farklı fikirler ileri sürmektedir. Bazı araştırmacılar, duygusal emeğin olumsuz sonuçlar doğuracağını ileri sürerken, bazıları da olumlu sonuçlarının olacağı kanısındadır. Duygusal emeğin olumsuz sonuçları ile ilgilenen araştırmacılar genellikle tükenmişlik ve iş tatminsizliği 
ile ilişki kurmakta(Hochschild, 1983; Wharton, 1993; Morris ve Feldman, 1996; Abraham, 1998; Grandey, 2000; Kim, 2008; Chu, Baker ve Murrmann, 2012); özsaygı, rol yabancılaşması, kendine yabancılaşma ve depresyon gibi çalışanın psikolojik refahı ile ilgili kavramlarla duygusal emeği ilişkilendirmektedir (Ashforth ve Humphrey, 1993; Fineman, 1993; Tolich 1993; Wharton, 1993). Buna karşın bazı nitel araştırmalar duygusal emeğin finansal kazanç, güven duygusu, özsaygı, öz yeterlilik ve iş tatmini artışı gibi olumlu sonuçlar doğuracağını ileri sürmektedir (Rafaeli ve Sutton, 1987; Ashforth ve Humphrey, 1993; Tolich, 1993; Wharton, 1993).

Duygusal emeğin öncüllerini araştıran çalışmalara bakıldığında; Kruml ve Geddes (2000)'in, duygusal emeğin öncüllerini (1) kişisel özellikler (cinsiyet, yaş, deneyim, duygudaşık yeteneği) ve (2) iş özellikleri (duygusal emeği gösterme eğilimi ve özgürlüğü, müşteri etkisi, kaliteye uyum sağlama ve duygusal bağlanma)şeklinde iki kısımda ele aldıkları görülmektedir.

Bireysel farklılıkları, duygusal emeğin öncülü şeklinde ele alan araştırmacılar; duygusal zekanın (Lopes, Salovey, Côté ve Beers, 2005), olumlu ve olumsuz duyguların (Brotheridge ve Grandey, 2002; Brotheridge ve Lee, 2003; Diefendorff,Croyle ve Grosserand, 2005), cinsiyetin (Rafaeli ve Sutton, 1989; Wharton, 1993; Pugh, 2002; Gross ve Jhon, 2003; Grandey; 2000) üzerinde durmuşlardır.

Ülkemizde yapılan çalışmaların birçoğunda da duygusal emeğin olumsuz etkileri üzerine durulmuştur. Duygusal emeğin olumsuz sonuçları araştırılırken duygusal emek ile tükenmişlik (Kaya ve Özhan, 2012; Yürür ve Ünlü, 2011; Basım ve Beğenirbaş, 2012; Oral ve Köse, 2011; Yıldırım ve Erul, 2013), işten ayrılma niyeti (Yürür ve Ünlü, 2011),işte kalma niyeti (Pala ve Tepeci, 2014), psikolojik sıkıntı ve iş-aile çatışması(Çelik ve Turunç, 2011), iş tatmini (Başbuğ, Ballı ve Oktuğ, 2010; Oral ve Köse, 2011; Pala ve Tepeci, 2014) ilişkilendirilmiştir. Başbuğ, Ballı ve Oktuğ (2010), çağıı merkezi çalışanları ile yaptıkları araştırma sonucunda; yüzeysel davranış sergileyen çalışanların iş tatminlerinin azaldığını tespit ederken Oral ve Köse (2011) de yüzeysel davranış sergileyen hekimlerin iş tatminlerinin azaldığını belirtmiştir. Benzer şekilde, Pala ve Tepeci (2014) yüzeysel davranış gösteren otel çalışanlarının iş tatminlerinin azaldığını, derin davranış sergileyenlerin iş tatminlerinin ise arttığını ileri sürmüştür.
Duygusal emek ile tükenmişlik arasındaki ilişkiyi hemşireler üzerinde inceleyen araştırmacılardan Yıldırım ve Erul (2013), duygusal emek davranışlarını tek boyutta ele alarak, duygusal emeğin tükenmişlik üzerinde olumsuz etkiye sahip olduğunu belirlemiştir. Oral ve Köse (2011) yüzeysel davranışın tükenmişliği arttırdığını bulgularken; Basım ve Beğenirbaş (2012) duygusal tükenme ve duyarsızlaşma ile yüzeysel davranış arasında pozitif, samimi davranış arasında negatif bir ilişki olduğunu belirtmekte ve tükenmişliğin kişisel başarı hissinde azalma boyutu ile derin ve samimi davranış arasında negatif bir ilişki bulgulamaktadırlar. Buna ek olarak, Kaya ve Özhan (2012), turist rehberlerinin derin ve samimi davranış gösterme düzeylerinin arttıkça duyarsızlaşma düzeylerinin azaldığını, kişisel başarı duygularının arttığını tespit etmiştir. Ayrıca duygusal emeğin işten ayrılma niyeti ile olan ilişkisine bakıldığında, Yürür ve Ünlü (2011) yüzeysel davranış ile işten ayrılma niyeti arasında pozitif bir ilişki bulurken Pala ve Tepeci (2014) derin davranış ve işte kalma niyeti arasında pozitif bir ilişkinin varlığını belirlemiştir. Duygusal emek ile iliş̧kisi en fazla araştırılan iş çıktıları; iş tatmini, tükenmişlik ve işte kalma niyetidir. Bu nedenle, bu iş çıktıları ile duygusal emek arasındaki ilişkiyi inceleyen araştırma sonuçlarına değinilmiştir. Bu sonuçlardan da anlaşılacağı gibi duygusal emek boyutlarından yüzeysel davranış boyutunun olumsuz etkileri diğer boyutlara göre fazladır.

\subsection{Duygusal Emek Boyutları}

Duygusal emek, çeşitli araştırmacılar tarafından çok boyutlu olarak ölçülmektedir. Hochschild (1983), duygusal emeği yüzeysel ve derin davranış olarak iki boyutlu bir yapıda kavramsallaştırırken; Ashforth ve Humphrey (1993), bu boyutlara samimi davranışı da ekleyerek duygusal emeği; yüzeysel, derin ve samimi davranış olarak üç boyutta ele almaktadır. Diefendorff, Croyle ve Grosserand (2005), Ashforth ve Humphrey (1993) ile benzer şekilde samimi davranışında içinde bulunduğu duygusal emeğin üç boyutlu (yüzeysel, derin ve samimi davranış) bir kavram olduğunu ileri sürmüştür. Naring, Briet ve Brouwers (2006) ise; yüzeysel davranış (surface acting), derin davranış (deep acting), duyguların bastırılması (suppresion) ve duygusal uyum (emotional consonance) olarak adlandırdıkları samimi davranışa ek olarak duyguların bastırılması boyutunu da ekleyerek dört boyutlu bir şekilde duygusal emeği kavramsallaştırmıştır. 
Kruml ve Geddes (2000) ise duygusal emeği, duygusal uyumsuzluk ve duygusal çaba olarak iki boyutta değerlendirmiştir. Lee ve Ok (2012) ise Kruml ve Geddes (2000)'in duygusal çaba ve duygusal uyumsuzluk boyutlarının yüzeysel, derin ve samimi davranışı kapsadığını söyleyerek duygusal uyumsuzluğun yüzeysel davranıştan, duygusal çabanın ise derin ve samimi davranıştan oluştuğunu belirtmiştir. Morris ve Feldman (1996) ise, duygusal emeği; duyguların gösterilme sıklığı, süresi, çeşitliliği ve yoğunluğu olarak dört boyutta kavramsallaştırmıştır.

Tüm bu çeşitli duygusal emek kavramsallaştırmalarını sınıflandıran Brotheridge ve Grandey (2002) duygusal emeği, iş odaklı ve çalışan odaklı duygusal emek olmak üzere iki yaklaşımda ele almıştır. Duygusal emeğin ilk yaklaşımı olan iş odaklı duygusal emek, iş özelliklerine odaklanmaktadır. İkinci yaklaşım olan çalışan odaklı duygusal emek ise, çalışanların duygularını yönetim süreçlerine odaklanmaktadır. İş odaklı duygusal emek yaklaşımı, duygusal ifadenin gösterim sıklığını, süresini, çeşidini ve yoğunluğunu içermektedir. Çalışan odaklı duygusal emek yaklaşımı ise, yüzeysel ve derin davranış boyutlarından oluşmaktadır. Bu çalışma, çalışanların kendi duygularını örgütün isteklerine göre düzenlemeleri ile ilgilendiğinden bu çalışmada yalnızca çalışan odaklı duygusal emek boyutları ele alınacaktır.

Hizmet işletmelerinde çalışanlar, hizmet karşılaşmaları boyunca duygusal ifadelerini kontrol eder veya değiştirirler. Bu duygusal ifadenin kontrolü veya değiştirilmesi, duygusal emeğin çalışan odaklı boyutları olan yüzeysel davranışın veya derin davranışın ortaya çıkışını belirler. Örneğin çalışanlar kötü bir ruh hali içerisindeyken ve zor bir müşteri ile uğraşırken, gülümsemesini belirginleştirir ya da sahte bir gülümseme ifadesi takınır. Çalışanların buna benzer bir davranış göstermesi yüzeysel davranış sergilediklerini gösterir. Derin davranış ise, örgüt tarafından belirlenen gösterim kurallarına uymak için içsel duyguların ve düşüncelerin kontrolü ile ilgili bir süreçtir (Brotheridge ve Grandey, 2002). Duygusal emeğin boyutları arasında yer alan yüzeysel ve derin davranışın yanında samimi davranışın da olması gerektiğini düşünen araştırmacılar bulunmaktadır
(Asforth ve Humphrey, 1993; Diefendorff, Croyle ve Grosserand, 2005). Ashforth ve Humphrey (1993) duygusal emek stratejilerine samimi davranışı da ekleyerek duygusal emek kavramsallaştırmasını bir adım öteye götürmüştür. Ashforth ve Humphrey samimi davranışı; çalışanın hissettiği duygunun örgütün ifade edilmesini istediği duygu ile aynı olması olarak tanımlar. Diefendorff, Croyle ve Grosserand (2005), samimi davranışın derin davranışın bir alt stratejisi olarak değil de yüzeysel davranış ve derin davranıştan farklı olarak ele alınması gerektiğini vurgular. Duygusal emek stratejileri olarak yalnızca yüzeysel ve derin davranışı ele alan çalışmalar, çalışanların kendiliğinden gerçekleşen, gerçekten hissettikleri ve örgütün ifade edilmesini istediği duygularla uyumlu olan duyguları dışarıda bırakırlar. Örneğin bir sosyal hizmet çalışanı, mağdur olan bir çocuğa gerçekten hissettiği için sempatik davranabilir ve bu durumda ne derin davranışa ne de yüzeysel davranışa ihtiyaç duyar (Ashforth ve Humphrey, 1993). Ayrica Ashforth ve Humphrey (1993), derin ve yüzeysel davranışın gösterilebilmesi için çalışanın çaba sarf etmesi gerektiğini ileri sürer. Samimi davranışın, müşteri ile iletişim içerisinde kendiliğinden oluşabileceğini düşünürken derin davranış ve yüzeysel davranış için odaklanmak gerektiğini düşünürler.

\subsection{Duygusal Emek Ölçekleri}

Yukarıda aktarılan duygusal emek boyutlarını yansıtan farklı duygusal emek ölçekleri geliştirilmiştir. Duygusal emek yazınında yer alan ölçekler, bu ölçeklerin hangi örneklemler üzerinde test edildiği, boyutları ve bu çalışmaların geçerlilik ve güvenilirlik sonuçları ile ilgili bilgilere Tablo 1'de yer verilmektedir.

Görüldüğü gibi duygusal emek, farklı boyutlarda ve farklı örneklemlerde ölçülmeye çalışılmıştır. Duygusal emeği ölçmek isteyen birçok çalışma, duyguların bastırılması boyutunu ayrı bir boyut olarak ele almamış, yüzeysel davranış boyutunun içerisine duyguların bastırı ması ile ilgili bazı ölçek maddelerini ekleyerek yer vermiştir. Bu maddeler, yüzeysel davranış boyutunun içerisinde örgütün istediği duyguları göstermek amacı ile gerçek duygularını gizlediklerini ifade eden maddelerden oluşmaktadır. 


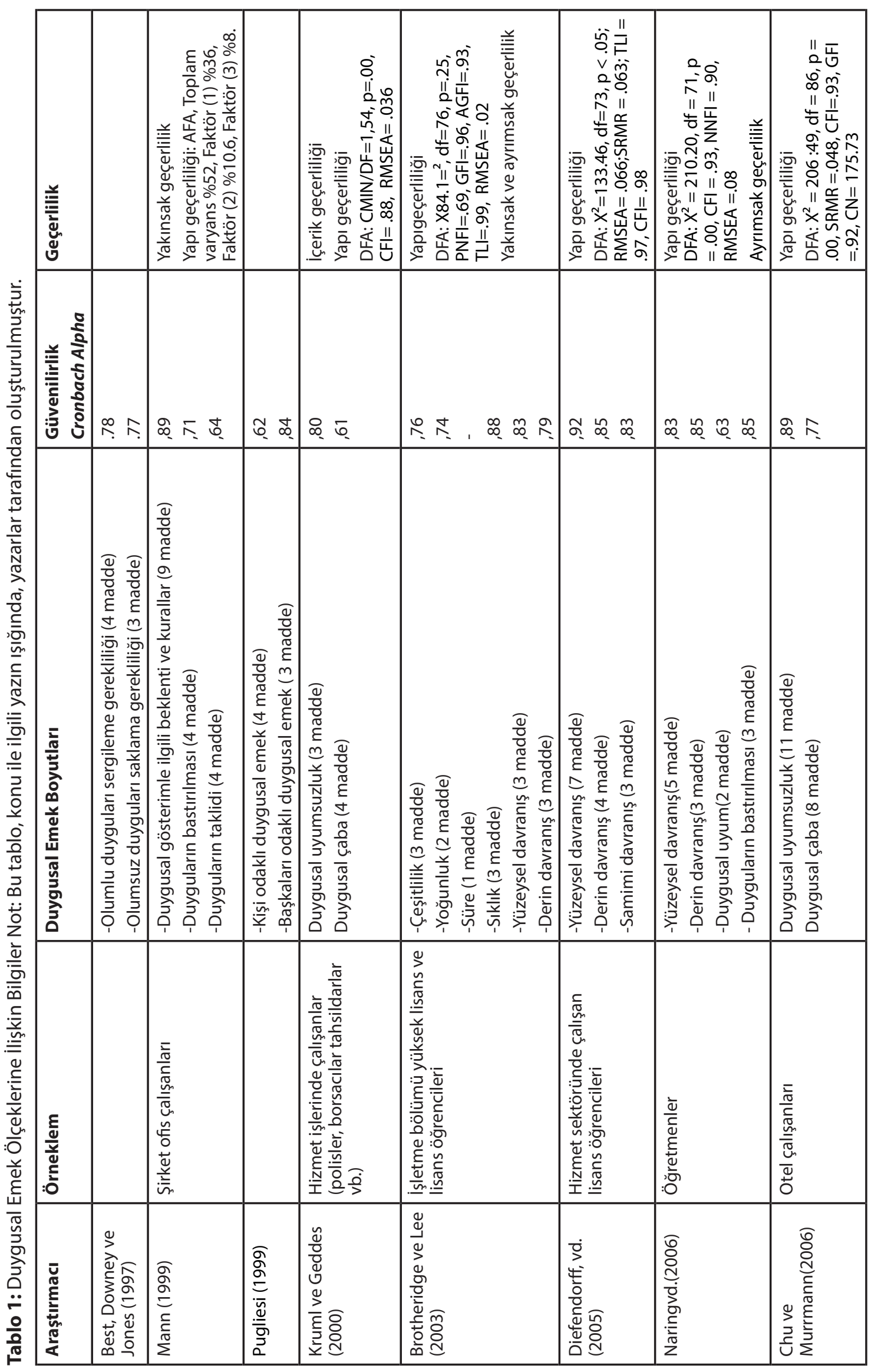




\subsection{Duygusal Emek Ölçeklerinin Türkçe 'ye Uyarlama Çalışmaları}

Yabancı yazında bulunan duygusal emek ölçeklerinden bazıları Türkçeye çevrilerek farklı örneklemler üzerinde test edilmiş ve duygusal emek boyutları belirlenmeye çalışılmıştır. Çukur (2009), öğretmenler üzerinde yaptığı duygusal emek ölçeği uyarlama çalışmasında, Diefendorff, Croyle ve Grosserand (2005) tarafından geliştirilen duygusal emek ölçeğini kullanmıştır. Orijinal ölçekte yüzeysel, derin ve samimi davranış olarak üç boyutlu bir yapı elde edilirken Çukur (2009) tarafından gerçekleştirilen uyarlama çalışmasında, derinden rol yapma, yüzeysel rol yapma, otomatik duygusal düzenleme ve duygusal sapma olarak isimlendirilen dört boyutlu bir yapı elde edilmiştir. Yüzeysel rol yapma, çalışanların hissetmedikleri duyguları işlerinin gerektirdiği şekilde göstermeleri, gerçekten hissettiklerini bastırmaları veya düzenlemeleri olarak tanımlanırken derinden rol yapma, çalışanların örgütün istediği duyguları gösterebilmek için duygularını önceden düzenlemeleri olarak ifade edilmiştir. Otomatik duygusal düzenleme ise, çalışanların işleri gereği gösterilmesi gereken duyguları önceden bir hazırlık yapmadan veya mevcut duygularını değiştirip düzenlemeden sergilemeleridir. Son olarak duygusal sapma, çalışanların örgütün istediği duyguları (ya da gösterim kurallarını) dikkate almadan hissettikleri duyguları ifade etmeleri olarak tanımlanmıştır.

Pala Morkoç (2014), konaklama sektöründe çalışanlar için Chu ve Murrmann (2006) tarafından geliştirilen HELS ölçeğini Türkçe'ye çevirerek geçerlilik ve güvenilirlik analizlerini yapmıştır. Otel çalışanları ile yapılan çalışmada, duygusal emek boyutları yüzeysel, derin ve samimi davranış olarak tespit edilmiştir. Basım ve Beğenirbaş (2012) çalışmalarında, Diefendorff, Croyle ve Grosserand (2005) tarafından geliştirilen duygusal emek ölçeğini Türkçeye uyarlayarak duygusal emek boyutlarını yüzeysel rol yapma (yüzeysel davranış), derinden rol yapma (derin davranış) ve doğal duygular (samimi davranış) olarak bulmuştur. Yürür ve Ünlü (2011) de Diefendorff, Croyle ve Grosserand (2005)'un ölçeğini Türkçeye çevirmiş,hizmet ve turizm sektöründe çalışanlarından topladığı veriler ile duygusal emeği yüzeysel ve derinlemesine davranış olarak iki boyutlu olarak tespit etmiştir. Durgut ve Kahya (2015), Brotheridge ve Lee (1998)'nin çalışmasından yararlanarak geliştirmiş olan Grandey (1999)'in duygusal emek ölçeğini Türkçeye çevirerek duygusal emek boyutlarını duygusal çaba harcama, yüzeysel davranış, gerçek duyguları bastırma, derinlemesine davranış şeklinde dört grupta belirlemiştir. Bu bilgiler Tablo 2'de özetlenmektedir.

Bu ölçeklerin Türkçe uyarlama çalışmaları; Türkiye'de duygusal emek ile ilgili yapılan çalışmalara yol göstermektedir. Bu çalışmaların amacı; yabancı yazında belirli örneklemler üzerinde test edilmiş ölçeklerin Türkçe yazına kazandırılması ve kullanıma sunulmasıdır. Ölçek uyarlama çalışmalarında görüldüğü üzere, farklı örneklemler üzerinde farklı ölçekler kullanılarak duygusal emek boyutları belirlenmeye çalışılmıştır. Bu farklıılıklar, ölçek boyutlarının isimlendirilmesine de yansımıştır. Ülkemizde yapılan çalışmalarda, duygusal emek boyutlarının aynı kavramı ifade etse dahi (örneğin samimi davranış ve otomatik duygusal düzenleme gibi) ayrı adlar alması, kavramlar ile ilgili kafa karışıklığına sebep olmaktadır. Bu çalışma, böyle bir kafa karışıklığına da bir çözüm bulma amacı ile, duygusal emek çalışmaları için temel olan belirli ölçekleri ele alıp bu ölçeklerdeki maddeleri gözden kaçırmamak için, madde havuzu oluşturarak ölçek geliştirmeyi hedeflemektedir. Ayrıca bu çalışmanın özgün yanlarından biri de "duyguların bastırılması" nı (Naring vd., 2006) bir duygusal emek boyutu olarak dikkate alarak duygusal emeğin boyutlarının yüzeysel davranış, duyguların bastıııması, derin davranış ve samimi davranış olarak dört boyutlu bir yapıda olabileceğini varsaymasıdır. 


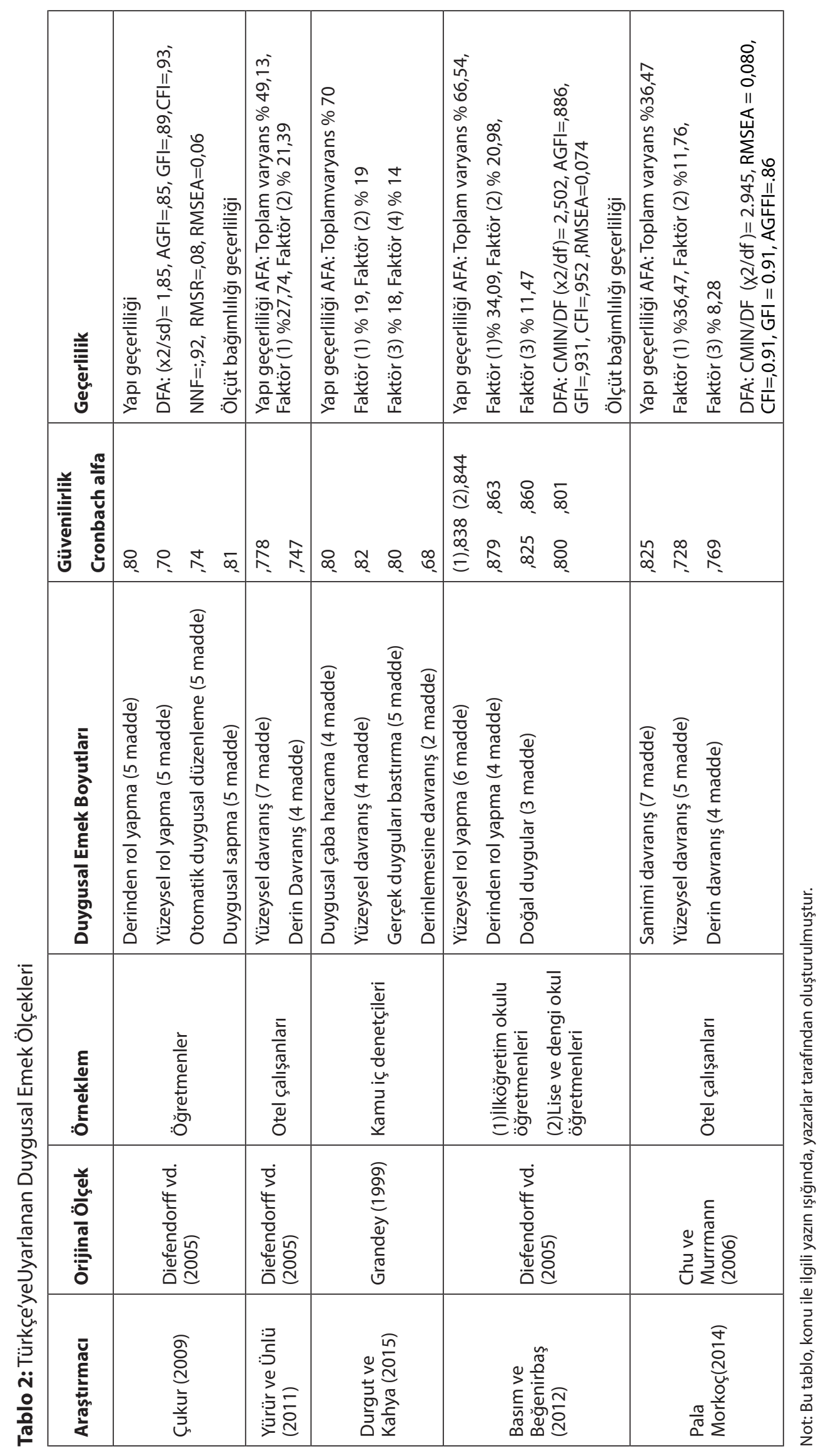




\section{YÖNTEM}

Çalışma yaşamında duygusal emek olgusunu ölçmeyi hedefleyen ölçeğin geliştirilmesinde beş aşamalı bir süreç izlenmiştir. Madde havuzu oluşturulması, kapsam geçerliliğinin test edilmesi, uygulama, yapı geçerliliğinin test edilmesi, güvenilirlik değerlerinin tespiti şeklindeki bu sürecin sonucunda, geliştirilen duygusal emekölçeğinin farklı örneklemler üzerinde test edilerek tüm hizmet sektörü için kullanılabilecek hale gelmesi hedeflenmektedir.

Öncelikle yabancı yazında geliştirilmiş başlıca duygusal emek ölçekleri incelenmiş ve ayrıca duygusal emek olgusunu açıklayabilecek farklı maddelere ulaşma amacıyla bir odak grup çalışması gerçekleştirilmiştir. Hizmet sektörünün farklı alanlarında (eğitim, turizm, sağlık gibi sektörlerde) ve insanlarla yüz yüze iletişim kurarak çalışan 6 kişi odak grup çalışmasında yer almıştır. Odak grup çalışmasında duygusal emeğin ne olduğu açıklanmış, iş yaşamlarında duygusal emek olarak nitelendirebilecekleri durumların neler olduğunu,bu anlarda neler hissettiklerini ve duygularını nası dışa vurduklarını dile getirmeleri istenmiştir. Odak grubu çalışmasında katılımcıların duygusal emek konusu ile ilgili tartışmaları incelenerek elde edilen 13madde(Bknz Tablo 3; Madde No: 9, 10, 11, 12, 13, $17,20,21,22,26,32,37,38$. maddeler) ve yabancı yazında yer alan duygusal emek ölçeklerinden 29 maddeyle birlikte bir madde havuzu oluşturulmuştur.

Uzman görüşü alma aşamasında; toplam 42 maddeden oluşan madde havuzu, duygusal emek alanındaki çalışmaları ile tanınan 5 uzman ile paylaşılmıştır. Uzmanlardan, maddeleri "kesinlikle gerekli-kesinlikle gereksiz" ölçeğinde değerlendirmeleri, ifadelere ilişkin önerilerde bulunmaları ve duygusal emek olgusunu açıkladığını düşündükleri yeni madde eklemelerinde bulunmaları istenmiştir. Uzmanlar tarafından toplam 4 yeni madde önerisi yapılmıştır. Ayrıca uzmanlar 26 maddenin ölçekte kesinlikle yer alması gerektiğini, 12 maddenin ölçekte yer alması gerektiğini, 4 maddenin ise ölçekte yer almasının gerekmediğini belirtmişlerdir. Uzmanlar tarafından gerçekleştirilen öneriler dikkate alınarak madde havuzu yeniden düzenlenmiş ve 38 maddelik bir soru formu oluşturulmuştur (Bknz: Tablo 3). Soru formu "Tamamen katılıyorum", "Katılıyorum", "Ortadayım", "Katılmıyorum" ve "Hiç katılmıyorum" şeklinde derecelendirilmiştir. Katılımcılardan soruları, işyerlerini ve çalışma yaşamlarını düşünerek yanıtlamaları istenmiştir.
Tablo 3: Madde Havuzu Oluşturulması ve Uzman Görüşü Sonrası Elde Edilen Maddeler

\begin{tabular}{|c|c|}
\hline \multicolumn{2}{|c|}{ İşyerimde (çalışırken); } \\
\hline 1 & Her zaman gülümsemek zorundayım. \\
\hline 2 & Ruh halime göre duygularımı kontrol ederim. \\
\hline 3 & İnsanlarla ilgilenirken kendim gibi davranmam. \\
\hline 4 & $\begin{array}{l}\text { İnsanlara karşı yüzeysel de olsa arkadaşça davranmam } \\
\text { gerekir. }\end{array}$ \\
\hline 5 & $\begin{array}{l}\text { İnsanlar nasıl davranırlarsa davransınlar, ben nazik } \\
\text { olmak zorundayım. }\end{array}$ \\
\hline 6 & $\begin{array}{l}\text { Kendimi sahnedeki bir oyuncuymuşum gibi } \\
\text { hissediyorum. }\end{array}$ \\
\hline 7 & $\begin{array}{l}\text { Durumları en uygun şekilde idare edebilmek için rol } \\
\text { yaparım. }\end{array}$ \\
\hline 8 & Taktiksel olarak insanları değerli hissettiririm. \\
\hline 9 & İnsanları dinlemesem de dinliyormuş gibi yaparım. \\
\hline 10 & $\begin{array}{l}\text { Tecrübe kazandıkça duygularımı daha rahat kontrol } \\
\text { ediyorum. }\end{array}$ \\
\hline 11 & $\begin{array}{l}\text { Duygularımı kontrol etmem günün saatlerine göre } \\
\text { değișiklik gösterir. }\end{array}$ \\
\hline 12 & $\begin{array}{l}\text { Yoğun tempolu ve işin çok olduğu günlerde } \\
\text { duygularımı kontrol etmekte zorlanırım. }\end{array}$ \\
\hline 13 & $\begin{array}{l}\text { İnsanların üzüntüleri saçma gelse de üzüntülerini } \\
\text { paylaşıyormuşum gibi yaparım. }\end{array}$ \\
\hline 14 & İnsanlarla ilgilenirken, gerçek duygularımı gizlerim. \\
\hline 15 & $\begin{array}{l}\text { İnsanların tehdit edici tavırlarına karşı korkumu } \\
\text { gizleyebilirim. }\end{array}$ \\
\hline 16 & $\begin{array}{l}\text { Hoşuma gitmeyen bir davranış karşısında, kızgınlığımı } \\
\text { gizleyebilirim. }\end{array}$ \\
\hline 17 & $\begin{array}{l}\text { Içimden gelen duyguları göstermek amatörce bir } \\
\text { tutumdur. }\end{array}$ \\
\hline 18 & Hayret verici durumlarda bile sakinliğimi koruyabilirim. \\
\hline 19 & $\begin{array}{l}\text { İnsanlara standart tepkiler verebilmek için duygularımı } \\
\text { bastırırım. }\end{array}$ \\
\hline 20 & İşimin ilk yıllarında duygularımı gizlemek daha zordu. \\
\hline 21 & $\begin{array}{l}\text { Bana zararı dokunur korkusu ile duygularımı } \\
\text { göstermem. }\end{array}$ \\
\hline 22 & $\begin{array}{l}\text { İşten atılma kaygısı nedeniyle duygularımı gizlemek } \\
\text { zorundayım. }\end{array}$ \\
\hline 23 & $\begin{array}{l}\text { Hislerimi değiştirmek için olaylara olumlu yönünden } \\
\text { bakmaya çalıșırım. }\end{array}$ \\
\hline 24 & Bana mutluluk veren şeylere odaklanmaya çalışııım. \\
\hline 25 & Olayları başkalarının bakış açısı ile değerlendiririm. \\
\hline 26 & $\begin{array}{l}\text { İnsanların sorunlarını dinler ve bu sorunlara çözüm } \\
\text { ararım. }\end{array}$ \\
\hline 27 & Çalışmaya başlarken güzel şeyler düşünürüm. \\
\hline 28 & $\begin{array}{l}\text { Göstermem gereken duyguları, gerçekten yaşamaya } \\
\text { çalışırım. }\end{array}$ \\
\hline 29 & İşim için gerekli olan duyguları benimserim. \\
\hline 30 & $\begin{array}{l}\text { İnsanlara karşı göstermiş olduğum konukseverlik } \\
\text { samimidir. }\end{array}$ \\
\hline 31 & $\begin{array}{l}\text { İşimi iyi yapabilmek için göstermem gereken duyguları } \\
\text { gerçekten hissederim. }\end{array}$ \\
\hline 32 & İnsanları mutlu etmeyi gerçekten seviyorum. \\
\hline 33 & Duygularımın bir şekilde açığa çıkmasına izin veririm. \\
\hline 34 & Sorun çıkartan kişilere kızgınlığımı söylerim. \\
\hline 35 & Sıkıntılı veya üzgün olan insanları rahatlatırım. \\
\hline 36 & İnsanlara karşı gerçekten sabırlıyımdır. \\
\hline 37 & Sinirli olan insanları sakinleştiririm. \\
\hline 38 & $\begin{array}{l}\text { Duygularımı yansıtmamam gerektiğini bildiğim halde } \\
\text { duygularımı ele veririm. }\end{array}$ \\
\hline
\end{tabular}

Anket yönteminden yararlanılan çalışmada kullanılan soru formuna, duygusal emeğe ilişkin bu 38 maddenin yanı sıra, 3 maddelik bir işten ayrılma 
niyeti ölçeği (Tepeci, 2005: 27-28) ve demografik sorular eklenmiştir. Yazılı soru sorma tekniği ile hizmet sektöründe faaliyet gösteren 810 katılımcıya anket iletilmiş, toplam 315 katılımcıdan yanıt alınmıştır (Geri dönüşüm oranı \%39).

\section{Katılımcıların demografik özellikleri} incelendiğinde, \%69'unun kadın \% 31'inin erkek; \%15'inin 16-25 yaş aralığında, \%48'inin 26-35 yaş aralığında, \%30'unun 36-45 yaş aralığında, \%6'sının 46-55 yaş aralığında ve yalnızca \%1'inin 56 ve üzeri yaş gurubunda olduğu belirlenmiştir. Katılımcıların \% 49'u lisans, \%32'si lisansüstü, \%12'si ön lisans, \%6'sı lise, \%1'i i ortaokul mezunudur. Katılımcıların; \% 36'sı eğitim, \%21'i sağlık, \%15'i turizm, \%4'ü hukuk, \%15'i özel, \% 7'si kamu, \% 2'si ise diğer sektörlerde (lojistik, tekstil, enerji ve inşaat sektörleri) çalıştıklarını beyan etmiş̧tir.

\section{BULGULAR}

Çalışmada öncelikle 38 maddeden oluşan soru formu aracılığıyla veri toplanmıştır. Duygusal emek olgusuna ilişkin 38 madde güvenilirlik analizine tabi tutulmuştur. İlk aşamada 8 ifade güvenilirliği düşürdüğü için madde havuzundan çıkarılmıştır.
Gerçekleştirilen açımlayıcı faktör analizleri sonrasında 10 ifade; 2 ya da daha fazla faktöre yakın yüklerle (0.10'dan daha az) dağıldığı için analiz dışında bırakılmıştır. Geri kalan maddelerden de boyut içi güvenilirliği düşüren maddeler çıkarıldığında toplam 12 madde kalmıştır. Söz konusu 12 madde tekrar faktör analizine tabi tutulmuştur. Analiz sonuçları Tablo 4'de yer almaktadır. Açımlayıcı faktör analizine göre Keiser-Meyer-Olkindeğeri 0,805 olarak tespit edilmiştir. Bartlett testine göre sonuçlar 0,000 düzeyinde anlamlıdır. 3 boyutun toplam varyansı açıklama yüzdesi \% 53.757 olarak belirlenmiştir. İlk boyut \% 31.258, ikinci boyut \% 11.884 ve üçüncü boyut \% 10.616 düzeyinde duygusal emek olgusunu açıklamaktadır.

İlk boyut, çalışanların işyerinde hissettikleri gerçek duygularını kendi içsel duygularını değiştirmeye çalışmadan yalnızca jest ve mimikler ile yüzeysel olarak dışa vurdukları için“yüzeysel davranış";ikinci boyut, işyerinde çalışanların gerçek duygularını bastırmaya çalıştıklarını ifade eden maddeleri barındırdığı için "duyguların bastırılması"; üçüncü boyut, çalışanların örgütün gösterilmesini istediği duyguları içsel olarak değiştirmeye çabaladıklarından dolayı "derin davranış" olarak adlandırılmıştır.

Tablo 4: Açımlayıcı Faktör Analizi Sonuçları

\begin{tabular}{|c|c|c|c|}
\hline $\begin{array}{l}\text { Maddeler } \\
\text { İşyerinde (çalışırken); }\end{array}$ & $\begin{array}{l}\text { Yüzeysel } \\
\text { Davranış }\end{array}$ & $\begin{array}{l}\text { Duyguların } \\
\text { Bastırılması }\end{array}$ & $\begin{array}{l}\text { Derin } \\
\text { Davranış }\end{array}$ \\
\hline İnsanlara karşı yüzeysel de olsa arkadaşça davranmam gerekir. & ,520 & & \\
\hline Kendimi, sahnedeki bir oyuncuymuşum gibi hissediyorum. & ,725 & & \\
\hline Durumları en uygun şekilde idare edebilmek için rol yaparım. & ,808 & & \\
\hline Taktiksel olarak insanları değerli hissettiririm. & 747 & & \\
\hline İnsanları dinlemesem de dinliyormuş gibi yaparım. &, 589 & & \\
\hline $\begin{array}{l}\text { İnsanların üzüntüleri saçma gelse de onların üzüntüsünü } \\
\text { paylaşıyormuşum gibi yaparım. }\end{array}$ & 614 & & \\
\hline İnsanların tehdit edici tavırlarına karşı korkumu gizleyebilirim. & &, 651 & \\
\hline $\begin{array}{l}\text { Hoşuma gitmeyen bir davranış karşısında, kızgınlığımı } \\
\text { gizleyebilirim. }\end{array}$ & & 708 & \\
\hline Hayret verici durumlarda bile sakinliğimi koruyabilirim. & &, 731 & \\
\hline $\begin{array}{l}\text { İnsanlara standart tepkiler verebilmek için duygularımı } \\
\text { bastırırım. }\end{array}$ & & 675 & \\
\hline $\begin{array}{l}\text { Hislerimi değiştirmek için olaylara olumlu yönünden bakmaya } \\
\text { çalışırım. }\end{array}$ & & & ,864 \\
\hline Bana mutluluk veren şeylere odaklanmaya çalışırım. & & & 742 \\
\hline
\end{tabular}


Boyut içi güvenilirlik analizi sonuçlarına göre yüzeysel davranış boyutunun güvenilirliği 0,778 ; duyguların bastırılması boyutunun güvenilirliği 0,684, derin davranış boyutunun güvenilirliği 0,531 olarak belirlenmiş ve boyutların güvenilirliklerinin orta-iyi düzeyde olduğu saptanmıştır.

Boyut-madde korelasyonu analizi sonrasında her bir maddenin kendi boyutu ile arasındaki korelasyonun 0,20 'den büyük olması beklenmektedir. Tablo 5 incelendiğinde; yüzeysel davranış boyutunun, maddeleri ile korelasyonu 0,539 ile 0,811 arasında; duyguların bastırılması boyutunun, maddeleri ile korelasyonu 0,689 ile 0,771 arasında; derin davranış boyutunun, maddeleri ile korelasyonu 0,799 ile 0,852 arasında gerçekleştiği için boyutları oluşturan maddelerin boyutlarla anlamlı ve yüksek derecede ilişkili olduğu bulgulanmıştır.

Tablo 5: Boyut Madde Korelasyonu

\begin{tabular}{|c|c|c|c|}
\hline $\begin{array}{l}\text { Maddeler } \\
\text { İsyerinde (çalışırken); }\end{array}$ & $\begin{array}{l}\text { Yüzeysel } \\
\text { Davranış }\end{array}$ & $\begin{array}{l}\text { Duyguların } \\
\text { Bastırılması }\end{array}$ & $\begin{array}{l}\text { Derin } \\
\text { Davranış }\end{array}$ \\
\hline İnsanlara karşı yüzeysel de olsa arkadaşça davranmam gerekir. &, $539 * *$ & & \\
\hline Kendimi, sahnedeki bir oyuncuymuşum gibi hissediyorum. &, $697 * *$ & & \\
\hline Durumları en uygun şekilde idare edebilmek için rol yaparım. &, $811 * *$ & & \\
\hline Taktiksel olarak insanları değerli hissettiririm. &, $746 * *$ & & \\
\hline İnsanları dinlemesem de dinliyormuş gibi yaparım. &, $665^{* *}$ & & \\
\hline $\begin{array}{l}\text { İnsanların üzüntüleri saçma gelse de onların üzüntüsünü } \\
\text { paylaşıyormuşum gibi yaparım. }\end{array}$ &, $662^{* *}$ & & \\
\hline İnsanların tehdit edici tavırlarına karşı korkumu gizleyebilirim. & &, $701 * *$ & \\
\hline Hoşuma gitmeyen bir davranış karşısında, kızgınlığımı gizleyebilirim. & &, $689 * *$ & \\
\hline Hayret verici durumlarda bile sakinliğimi koruyabilirim. & & ,704** & \\
\hline İnsanlara standart tepkiler verebilmek için duygularımı bastırııım. & &, $771 *$ & \\
\hline $\begin{array}{l}\text { Hislerimi değiştirmek için olaylara olumlu yönünden bakmaya } \\
\text { çalışırım. }\end{array}$ & & &, $852^{* *}$ \\
\hline Bana mutluluk veren şeylere odaklanmaya çalışırım. & & & ,799** \\
\hline **Korelasyonlar 0.01 düzeyinde anlamlıdır. & & & \\
\hline
\end{tabular}

Açımlayıcı faktör analizinden sonra yapı geçerliliğinin sağlanması için Lisrel8.1programı aracılığıyla doğrulayıcı faktör analizi gerçekleştirilmiştir. Doğrulayıcı faktör analizi aşağıdaki şekilde gösterilmektedir. 


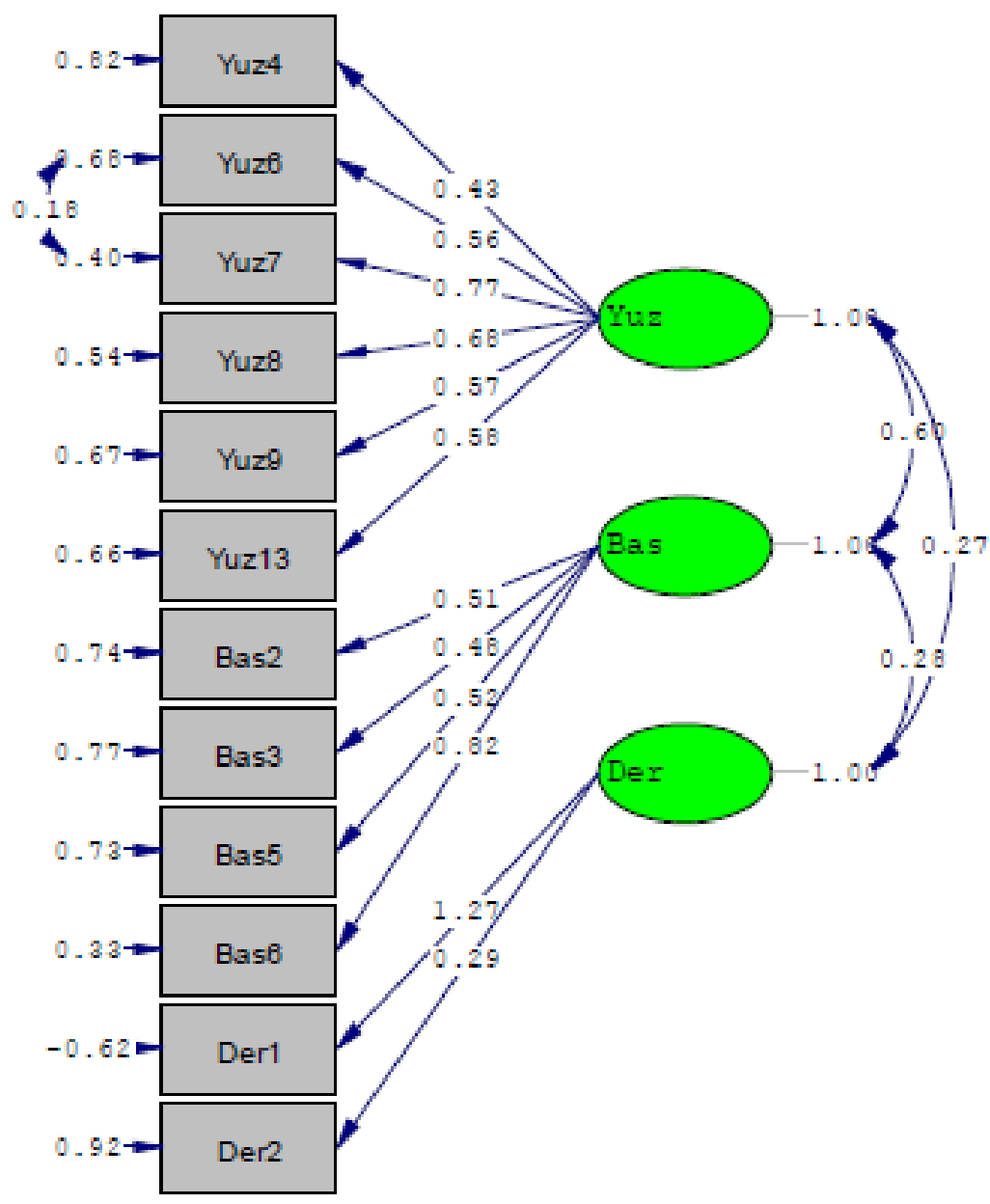

Şekil 1: Doğrulayıcı Faktör Analizi

Doğrulayıcı faktör analizi sonucunda elde edilen uyum iyiliği indisleri Tablo 6'da gösterilmektedir. İndisler, iyi uyum göstermektedir.

Tablo 6: Doğrulayıcı Faktör Analizi Uyum İyiliği İndisleri

\begin{tabular}{|l|c|c|c|}
\hline İndis & Değer & Olması Gereken & Sonuç \\
\hline X2/df & $72,60 / 50=1,452$ & $<2$ & İyi uyum \\
\hline NFI & 0,95 & $>0,90$ & İyi uyum \\
\hline NNFI & 0,98 & $>0,90$ & İyi uyum \\
\hline CFI & 0,98 & $>0,90$ & İyi uyum \\
\hline IFI & 0,98 & $>0,90$ & İi uyum \\
\hline AGFI & 0,94 & $>0,90$ & Iyi uyum \\
\hline GFI & 0,96 & $>0,90$ & İyi uyum \\
\hline RMSEA & 0,038 & $<0,05$ & İyi uyum \\
\hline RMR & 0,042 & $<0,05$ & \\
\hline
\end{tabular}


Doğrulayıcı faktör analizi sonuçlarının da modelin anlamlı olduğunu göstermesi sonucunda boyutlar arası korelasyon testi gerçekleştirilmiştir. Ölçek içi boyutların korelasyonunun çok yüksek olmaması istenmektedir $(<0,700)$. Aşağıda da görüldüğü gibi ölçek boyutları arasındaki korelasyonlar , 198 ve ,410 arasındadır.

Tablo 7: Boyutlar Arası Korelasyon Analizi

\begin{tabular}{|l|c|c|c|}
\hline Boyutlar & YüzeyselDavranış & Duyguların Bastırılması & DerinDavranış \\
\hline Yüzeysel Davranış & 1 & & \\
\hline Duyguların Bastırılması &, $410^{* *}$ & 1 & \\
\hline Derin Davranış &, $240^{* *}$ &, $198^{* *}$ & 1 \\
\hline
\end{tabular}

** $p<0.01$

Elde edilen 12 maddeden oluşan üç boyutlu ölçek yapısı ile duygusal emek ile ilişkisi en çok araştırılan değişkenlerden biri olan işten ayrılma niyeti ile de ilişkilendirilmiştir (Korelasyon analizi için Bknz: Tablo 8).

Tablo 8: Duygusal Emek Alt Boyutları ile İşten Ayrılma Niyeti Arasında Korelasyon Analizi

\begin{tabular}{|l|c|c|c|}
\hline Boyutlar: & Yüzeysel Davranış & Duyguların Bastırılması & Derin Davranış \\
\hline İşten Ayrılma Niyeti &, $220^{* *}$ &, 074 &, 023 \\
\hline
\end{tabular}

** $p<0.01$

Duygusal emek boyutlarıyla, işten ayrılma niyeti arasındaki ilişki değerlendirildiğinde; sadece yüzeysel davranış ve işten ayrılma niyeti arasında pozitif ve anlamlı $(t=3,15)$ bir ilişki olduğu görülmektedir. Bu bulgu; Yürür ve Ünlü (2011)'nün bulgularıyla tutarlılık göstermektedir.

\section{SONUÇ}

Bu çalışma; "duygusal emek" olgusunu ölçmeye yönelik, Türkiye'deki hizmet sektörü çalışma koşullarına uygun bir ölçme aracı geliştirmek amacıyla gerçekleştirilmiş̧ir. Bu amaç doğrultusunda çalışmada; öncelikle duygusal emek kavramı tanıtılmıs, duygusal emeğin boyutları hakkında bilgi verilmiş, yazında yer alan farklı ölçme araçları ve boyutları ile Türkçe yazına kazandırılan ölçeklere ilişkin bilgiler sunulmuştur. Ardından ölçek geliştirme süreci hakkında bilgi verilmiştir.

Çalışmada; yazında bulunan yüzeysel davranışı, duyguların bastırılması, derin davranışı ve samimi davranışı temsil eden ölçek maddeleri ile ölçek geliştirme çalışmasına gidilmiştir. Ölçek geliştirme sürecinde, yazında duygusal emeği ölçen ölçekler incelenmiş ve odak grup çalışması sonucunda ortaya çıkan ölçek maddeleri ile birlikte geliştirilmek istenen duygusal emek ölçeğine dahil edilmiştir.
Yazın incelemesi ve odak grup çalışmasından elde edilerek oluşturulan bu madde havuzu çalışmasından hareketle gerçekleştirilen alan araştırması ve hizmet sektörünün çeşitli meslek kollarında yer alan çalışanlardan toplanan verilerin açımlayıcı ve doğrulayıcı faktör analizlerine tabi tutulmasının ardından; 12 maddeden oluşan 3 boyutlu bir yapıya ulaşılmıştır. Bu boyutlar yazınla uyumlu şekilde yüzeysel davranış, duyguların bastırılması ve derin davranış şeklinde isimlendirilmiştir. Elde edilen 12 maddenin beş tanesi Best, Downey ve Jones (1997)'un; bir tanesi Hochschild (1983)'in, bir tanesi Pugliesi (1999)'nin, bir tanesi Chu ve Murrman (2006)'ın, bir tanesi Grandey, Dickter ve Sin (2004)'in ölçeğinde ve geri kalan üç tanesi de odak grup çalışmasında yer almaktadır.

Çalışmanın başlangıcında araştırmacılar tarafından varsayılan ve yazında farklı şekillerde yer alan dört boyutlu yapı (yüzeysel davranış, derin davranış, duyguların bastırılması, samimi davranış) yerine, üç boyutlu bir yapıya ulaşılmıştır. Nitekim, Grandey ve Gabriel (2015) duygusal emek çalışmalarının geleceği ve yapılacak olan çalışmaların hangi yönde olması gerektiğiyle ilgili tavsiyelerinde, mevcut araştırmaların çoğunda yer alan yüzeysel ve derin davranış boyutlarından oluşan ölçeklerin 
ötesine gidilmesi gerektiğinden söz etmiştir. Bu çalışmada elde edilen ölçekte de daha önceki çalışmalarda kullanılan çeşitli duygu düzenleme stratejilerine yer verilmiştir.

Samimi davranışın analizler sonucunda duygusal emek ölçeğinde yer alamamış olması duygusal emeği; çalışanların duygularını örgütün istediği şekilde yönetmesi (Hochschild, 1983), bu duyguları göstermek için çaba sarf etmesi veya gösterilmesi istenmeyen duyguları kontrol etmesi olarak tanımlayan araştırmacıları (Morris ve Feldman, 1997) destekler niteliktedir. Benzer şekilde Mann (1996), duygusal emeğin ortaya çıkabilmesi için duygusal uyumsuzluğun var olması gerektiğini, gösterilmesi istenen duygular ile çalışanın hissettiği duyguların aynı olduğu durumların duygusal emek olamayacağını savunarak samimi davranış boyutunu duygusal emeğin dışında tutmaktadır.

Bu çalışma, hizmet sektörünün çeşitli meslek kollarında yüz yüze iletişim kuran çalışanlardan veri toplanarak yapılmıştır. Hizmet sektöründeki meslek kollarının çeşitliliği ve yüz yüze iletişim kurma derecelerinin birbirinden farklı olması bu çalışmanın kısıtıdır. Gelecekte yapılacak olan çalışmalar, hizmet sektöründe yer alan belirli meslek grupları ile tüm ölçek maddeleri dikkate alınarak yapılabilir ve belirli meslek gruplarına yönelik çalışmalarda da gerek samimi davranış gerekse farklı duygusal emek boyutları araştırılabilir.

\section{KAYNAKLAR}

Abraham, R. (1998)“EmotionalDissonance in Organizations: Antecedents, Consequences, and Moderators"Genetic, Social, and General Psychology Monographs. 124: 229-246.

Ashforth, B. E. ve Humphrey, R. H. (1993)“Emotional Labor in Service Roles: Influence of identity"Academy of Management Review,18: 88-115.

Avcı, U. ve Boylu, Y. (2010)“Türk Turizm Çalışanları için Duygusal Emek Geçerlemesi"SOID Seyahat ve Otel işletmeciliği Dergisi, 7(2): 20-29.

Basım, H. N. ve Beğenirbaş, M. (2012) "Çalışma Yaşamında Duygusal Emek: Bir Ölçek Uyarlama Çalışması "Yönetim ve Ekonomi. 19(1): 77-90.

Basım, H. N. ve Beğenirbaş, M. (2013)“Duygusal Emekte Bazı Demografik Değişkenlerin Rolü" Çankaya University Journal of Humanities and Social Sciences 10(1): 45-57.

Başbuğ G., Ballı, E., Oktuğ, Z. (2010) "Çağrı Merkezi Çalışanlarının Sergiledikleri Duygusal Emeğin ve Sonuçlarının Niceliksel ve Niteliksel Olarak Araştırılması"iÜ İktisat Fakültesi Yayınları Sosyal Siyaset Konferansları Dergisi, 605(58): 253-274.

Beğenirbaş, M. ve Meydan, C. H. (2012) "Duygusal Emeğin Örgütsel Vatandaşlık Davranışıyla İlişkisi: Öğretmenler Üzerinde Bir Araştırma"İktisadi İdari Bilimler Fakültesi Dergisi, 4(3):1-24.

Beğenirbaş, M. ve Turgut, E. (2014)“iş̧ Performansının Sağlanmasında Çalışanın Duygusal Emeğinin ve Örgütte Güven Algısının Etkileri" "Işs, Güç" Endüstri Ilişkileri ve Insan Kaynakları Dergisi, 16(3):131-149.
Brotheridge, C. M. ve Grandey, A. A. (2002)“Emotional Labor and Burnout: Comparing Two Perspectives of People Work"Journal of VocationalBehaviour.60: 1739.

Brotheridge, C. M. ve Lee, R. T. (2003)“Development and Validation of the Emotional Labour Scale"Journal of Occupational and Organizational Psychology, 76: 365-379.

Chu, K. H. ve Murrmann, S. K. (2006)“Devolepment and Validation of the Hospitality Emotional Labor Scale"Tourism Management . 27: 1181-1191.

Chu, K. H., Baker, M. A. ve Murrmann, S. K. (2012)“WhenWeareOnstage, We Smile: The Effect of Emotional Labor on Employee Work Outcomes "International Journal of Hospitality Management,31: 906-915.

Çelik, M. ve Turunç, Ö. (2011) “Duygusal Emek ve Psikolojik Sıkıntı: İş-Aile Çatışmasının Aracılık Etkisi"Kuram ve Uygulamada Eğitim Bilimleri, 9(2): 527574.

Çukur, C. Ş. (2009)“Öğretmenlerde Duygusal İşçilik Ölçeği Geliştirme: Geçerlik ve Güvenirlik Çalışması"İstanbul Üniversitesi Işletme Fakültesi Dergisi, 9(2): 527-574.

Diefendorff, J. M.,Croyle M. H. ve Grosserand, R. H. (2005)"The Dimensionality and Antecedents of Emotional Labor Straregies "Journal of Vocational Behavior, 66: 339-357.

Durgut, M. ve Kahya, C. (2015)“Duygusal Emek ve Örgütsel Sessizlik Arasındaki İlişki "Yönetim ve Ekonomi Araştırmaları Dergisi, 13(1):348-364. 
Fineman, S. (1993) "Organizations As Emotional Arenas "Fineman, S. (ed.)Emotion in Organizations. Canada,Newbury Park.

Glomb, T. M. ve Tews, M. J. (2004)“EmotionalLabor: A Conceptualization and Scale Development" Journal of Voucational Behaviour, 64: 1-23.

Grandey, A. (2000) "Emotion Regulation İn The Workplace: A New Wayto Conceptualize Emotional Labor" Journal of Occupational Health Psychology, 5: 95-110.

Grandey, A. A. ve Gabriel A. S. (2015)“EmotionalLabor at a Crossraods: Where Do WeGofrom Here? "The Annual Review of Organizational Psychology and Organizational Behavior, 2: 323-349.

Gross, J. J. ve John, O. P. (2003)“IndividualDifferences in Two Emotion Regulation Processes: Implications for Affect, Relationships, and Well-Being"Journal of Personality and Social Psychology. 85(2): 348-362.

Hochschild, A. R. (1983)The Managed Heart: The Commercialization of Human Feeling, Berkeley,Univ. of California Press.

Kaya, U. ve Özhan, K. Ç. (2012)“Duygusal Emek ve Tükenmişlik İlişkisi: Turist Rehberler Üzerine Bir Araştırma"Çalışma İlişkileri Dergisi, 3 (2): 109-130.

Kim, H. J. (2008) “Hotel Service Providers' Emotional Labor: The Antecedents and Effects on Burnout"International Journal of Hospitality Management,27: 151-161.

Kruml, S. M. ve Geddes, D. (2000)“Exploring the Dimensions of Emotional Labor: Hochschild's Work "Management Communication Quarterly, 14: 8-49.

Lee, J. J. ve Ok, C. (2012)“ReducingBurnouta ndEnhancingJobSatisfaction: Critical Role of Hotel Employees' Emotional Intelligence and Emotional Labor"International Journal of Hospitality Management, 31: 1101-1112.

Lopes, P. N.,Salovey, P., Côté, S. ve Beers, M. (2005)“EmotionRegulationAbilitiesandtheQuality of Social Interaction"Emotion, 5(1): 113-118.

Mikolajczak, M.,Tran, V., Brotheridge, C. M. ve Gross, J.J. (2009)“Using an Emotion Regulation Framework to Predict the Outcomes of Emotional Labor"Emotions in Groups, Organizaitons and Cultures Research on Emotion Organizations, 5: 245-273.

Morris, J. A. ve Feldman, D. C. (1996)“TheDimensions, Antecedents, and Consequences of Emotional Labor"Academy of Management Review,21(4): 9061010.
Morris,J.A.veFeldman,D.C.(1997)“ManagingEmotions in the Workplace"Journal of Managerial Issues, 9(3): 257-274.

Naring, G.,Briet, M., Brouwers, A. (2006)“Beyond Demand-Control: Emotional Labor and Symptoms of Burnout in Teachers"Work\&Stress, 20(4):303-315.

Oktuğ, Z. (2013)“Algılanan Örgütsel Destek ile Duygusal Emek Davranışları Arasındaki İlişkide Algılanan Örgütsel Prestijin Biçimlendirici Etkisi "Elektronik Sosyal Bilimler Dergisi, 12(46):370-381.

Oral, L. ve Köse, S. (2011)“Hekimlerin Duygusal Emek Kullanımı ile İş Doyumu ve Tükenmişlik Düzeyleri Arasındaki İlişkiler Üzerine Bir Araştırma"Süleyman Demirel Üniversitesi Iktisadi ve Idari Bilimler Fakültesi Dergisi. 16(2): 463-492.

Öz, E.Ü. (2007). Duygusal Emek Davranışlarının Çalışanların İş Sonuçlarına Etkisi,İstanbul, Beta Basım Yayım Dağıtım A. Ş.

Öz, C. S. ve Man, F. (2007)"Çalışan Bedeninin Düşen Son Kalesi: Duygular Çağrı Merkezi Çalışanlarının Duygusal Emek Süreçleri"Sakarya Üniversitesi Ulusal Yönetim ve Organizasyon Kongresi Bildiriler Kitabı: 624-632.

Pala, T. ve Tepeci, M. (2014)“Otel İşletmelerinde Çalışanların Duygusal Emek Boyutlarının Belirlenmesi ve Duygusal Emek Boyutlarının İş Tatmini ve İşte Kalma Niyeti Üzerine Etkisi"Seyahat ve Otel Işsletmeciliği Dergisi, 11(1):21-37.

Pala Morkoç, T. (2014) "Otel Çalışanlarında Duygusal Emek Ve İş-Aile Çatışması İlişkisi: İzmir Şehir Otelleri Örneği"Yayınlanmamış Doktora Tezi, İzmir, Dokuz Eylül Üniversitesi Sosyal Bilimler Enstitüsü

Rafaeli, A. ve Sutton, R. (1987)“Expression of Emotion as Partof the Work Role"Academy of Management Review, 1: 23-37.

Tolich, M.B. (1993)"AlienationandLiberatingEmotions At Work"Journal of Contemporary Ethnography,22: 361-381.

Tepeci, M. (2005)"TheDimensionsandlmpacts of Organizational Culture on Employee Job

Satisfaction and Intent to Remain in the Hospitality and Tourism Industry in Turkey"Journal of Travel and Tourism Research, 5(1/2): 21-39

Türkay, O., Ünal, A. ve Taşar, O. (2011) “Motivasyonel ve Yapısal Etkenler Altında Duygusal Emeğin İşe Bağlılığa Etkisi"ZKÜ Sosyal Bilimler Dergisi. 7(14): 202222.

Wharton, A. S.ve Erickson, R. J. (1993 )“Managing Emotions on the Job and at Home: Understanding 
the Consequences of the Multiple Emotional Roles"Academy of Management Review,18(3): 457495.

Yıldırım, M. H. ve Erul, E. E. (2013)“Duygusal Emek Davranışlarının İşgörenlerin Tükenmişlik Düzeylerine Etkisi"Organizasyon ve Yönetim Bilimleri Dergisi, 5(1):89-99.
Yürür, S. ve Ünlü, O. (2011)“Duygusal Emek, Duygusal Tükenme ve İşten Ayrılma Niyeti İlişkisi" "İş, Güç" Endüstri İlişkileri ve Insan Kaynakları Dergisi,13 (2): 81 104. 